\title{
Potentiality of Biodiesel Production From Non-Edible Oil: Bangladesh Perspective
}

\author{
Kaniz Ferdous ${ }^{1}$, M. Rakib Uddin ${ }^{1 *}$, Rehnuma Islam ${ }^{1}$, Maksudur R. Khan ${ }^{1,2,}$, M. A. Islam ${ }^{1}$ \\ ${ }^{1}$ Department of Chemical Engineering and Polymer Science, Shahjalal University of Science and Technology (SUST), \\ Sylhet 3114, Bangladesh. \\ ${ }^{2}$ Faculty of Chemical and Natural Resources Engineering, Universiti Malaysia Pahang, 26300 Gambang, Kuantan, \\ Pahang, Malaysia.
}

\begin{abstract}
The present study focuses potentiality of biodiesel production in Bangladesh from non-edible oil. The increasing demands of energy are consumed by using fossil fuels which are non-renewable and will be depleted within 150 years from now if this growth rate stays but if this rate increases further the depleting time will decrease from the estimated one. Because of low reservation of crude oil, Bangladesh has to import oils from other countries, these costs a lot. About $95 \%$ of these demands can be meted through biodiesel. Biodiesel prepared from both edible and non-edible oils. After meeting demands of edible oil of the country it is impossible to produce biodiesel from edible oils. But it is possible to meet the biodiesel demand of the country almost $100 \%$ through non-edible oil derived biodiesel. Arable lands of Bangladesh can't be used for the growing purposes of non-edible oil seeds, but if rail and road sides are used there is no need for extra lands. After surveying lands for this purpose it seems that Bangladesh can get a total amount of $47750 \mathrm{Km}$ of road and rail side areas for the cultivation of non-edible seeds. Among these forest seeds Nageswar, Pitraj, Sultana champa Ponyal, Rata, Oil palm, Chaulmoogra, Bakul, Kusum, jaina have sufficient oil content along with plenty of growth in Bangladesh. Cultivating these seeds 1100000 tones of biodiesel can be produced on the basis of their oil content and yield. Which decreases the amount of imported crude oil as well as meets the oil demand of the country, thus Bangladesh can be able to save about $\$ 6$ billion per year means a great economic savings that can be used for the development of the country.
\end{abstract}

\section{INTRODUCTION}

Energy supply of the world has heavily relied on nonrenewable crude oil for more than two centuries. It also known that emissions from the combustions of these fuels such as $-\mathrm{CO}_{2}, \mathrm{CO}, \mathrm{NO}_{\mathrm{x}}$ sulfur containing residues are the principle causes of global warming and many countries have passed legislation to arrest their adverse environmental consequences [1]. With the rapid growth of population and the expanding industrial base and output in many developing countries, the demand of energy throughout the world is increasing day by day. If this situation continues the oil reserves could be depleted in less than fifty years [1]. On the basis of this problem the word 'Alternative Renewable Energy' is introduced. Solar energy, biomass, biogas, biodiesel, wind power, tidal energy etc. is some alternative energy sources. Because of the easy convertibility from a wide range of renewable sources and direct use in automobile engine without any modification, 'Biodiesel' is getting our attention increasingly as an alternative, non-toxic, biodegradable and renewable diesel fuel. Higher oxygen content, lower percentage of particulate matter, CO, sulfur content, polyaromatics, hydrocarbons, smoke and noise differentiates biodiesel from petroleum diesel. As vegetable-based fuels are made from agricultural materials which are produced via photosynthetic carbon fixation thus burning of such fuels does not contribute to the net atmospheric $\mathrm{CO}_{2}$ levels [2].
Bangladesh has small reserves of oil and coal, but potentiality for natural gas resources is very high. Commercial energy consumption is around $71 \%$ natural gas, with the remainder almost entirely oil (plus limited amounts of hydropower and coal). From 'U.S. Energy Information Administration' analysis Bangladesh had 0.03 billion barrels proved oil reserves in 2009 [3]. The oil production of the country per day was about 5.72 thousand $\mathrm{bbl} /$ day and crude oil production was about 5.00 thousand bbl/day. But the oil consumption of the country was about 94.07 thousand bbl/day. Fossil fuels are non-renewable energy sources and these sources can be depleted one day because of the high population growth rate and effects a lot on economic development. Coal and oil can be depleted within 155 years and gas can be depleted within 100 years which is estimated using per year energy consumption rate. So it urgent to found a new source for energy supply which can be biodiesel, a renewable energy prepared from different types of edible and non-edible oil seeds [4].

The energy demand of Bangladesh is so high as well as its population, but its production capability of oil sources not too high. If edible oil seeds are used for biodiesel production then it is not possible to meet the food oil demand of the country and additional land acquiring is also impossible because of the extreme limitation of lands [5]. As Bangladesh is an agricultural country thus if it is possible to increase edible oil production then we can be able to produce biodiesel which is economically feasible for us. But edible oil 
consumption for food is much higher than production [6]. So if we be able to produce more oil there is no probability to use it in the production of biodiesel. Thus in the aspect of Bangladesh the only reliable field is non-edible oil seeds. In our country most of these nonedible oil seeds found no use and being thrown off. Now-a-days biodiesel is also produced from non-edible oils because of its low price and no use as edible oil. Among all the forest seeds Nageswar, Pitraj, Sultana champa Ponyal, Rata, Oil palm, Chaulmoogra, Bakul, Kusum, jaina have sufficient oil content. These trees can be planted in the roadsides and rail sides of the country [7].

Bangladesh imported 916,000 tons of diesel and furnace oil per year $[3,8]$. By using the potential sources for biodiesel production, we can reduce the dependency on imported oils. Oil content, biodiesel yield varies with the variation of seed [9, 10]. According to this oil contents and yields we prepared estimation on biodiesel production from different non-edible oil seeds which can be planted through the rail and road sides of Bangladesh. In the present study a survey was done for estimating the total road and rail side for non-edible oil seed plantation. From this estimation it is seen that about 2387,500 ton seeds can be produced per year which supplies 1322,235 ton oil leading with 1001,881 ton biodiesel. That means a great opportunity for Bangladesh to survive a long time along with the developed world. By using the unused land we can produced biodiesel and save huge amount of foreign currency.

\section{METHODOLOGY}

\subsection{Biodiesel preparation methods}

Biodiesel can be prepared by the following methods:

1. Transesterification

2. Two-step method

3. Three-step method

2.1.1 Transesterification: Biodiesel was mainly produce by transesterification reaction describe by Guerreiro et. al., (2006) [11], Dora et. al., (2007) [12]. This transesterification reaction carried out by following ways [13, 14].

1. Base catalyzed transesterification.

2. Acid catalyzed transesterification.

3. Enzyme catalyzed transesterification.

4. Heterogeneously catalyzed method.

In the Transesterification reaction different types of oil and lipid are reacted with an alcohol in presence of acid or base catalyst to form esters and a by-product glycerol. The reaction is reversible and thus an excess amount of alcohol is usually used to force the equilibrium to the product side. The diagram of transesterification process is shown in Fig. 1.

2.1.2 Two-step method: Biodiesel production from high free fatty acid containing oil needs a two-step transesterification process i.e., acid catalyzed esterification followed by alkali catalyzed transesterification to get high biodiesel yield [15]. For acid catalyzed esterification usually $\mathrm{H}_{2} \mathrm{SO}_{4}$ was used as catalyst. For base catalyzed transesterification process $\mathrm{NaOH}$ was used as catalyst and methanol was used as alcohol. Instead of methanol and $\mathrm{NaOH}$, ethanol or $\mathrm{KOH}$ can also be used for making biodiesel. Methanol and $\mathrm{NaOH}$ were used for lower cost and higher conversion efficiency.

2.1.3 Three- step method: Required amount of raw oil was reacted with different stoichiometric amounts of alcoholic sodium hydroxide solution [16]. Take certain amount of oil in a three-necked flask and mix different stoichiometric amount of alcoholic sodium hydroxide solution. The mixture was heated under reflux with vigorous stirring at temperature of $65{ }^{0} \mathrm{C}$ for different time. After saponification, the soap solution was treated with concentrated hydrochloric acid at a temperature of $60-70{ }^{0} \mathrm{C}$ with vigorous stirring [16]. After dissolving the soap the fatty acid contents were separated in separatory funnel. After separation given hot water wash for removing mineral acid from the fatty acid. FFA (Free Fatty Acid) produced after acidification, was reacted with methanol at a temperature of $60{ }^{\circ} \mathrm{C}$ in presence of acid catalyst [21]. The diagram of three-step method is shown in Fig. 2.

\subsection{Necessity for the conversion of biodiesel from oil}

Biodiesel is a mono alkyl derived from vegetable oils. The direct use of vegetable oils in diesel engines can pose problems because of their higher viscosity. Thus in order to get less engine modification and efficient performance the vegetable oils are converted to their methyl esters, which have low viscosity. For decreasing viscosity vegetable oils are allowed to react with methyl alcohol in the presence of a catalyst to form methyl ester. In additions biodiesel has a higher cetane number and an indicator of fuel ignition efficiency, there is no sulphur content [17]. Moreover, the biofuel fraction in diesel is biodegradable, non-toxic and high oxygen content for efficient combustion. 


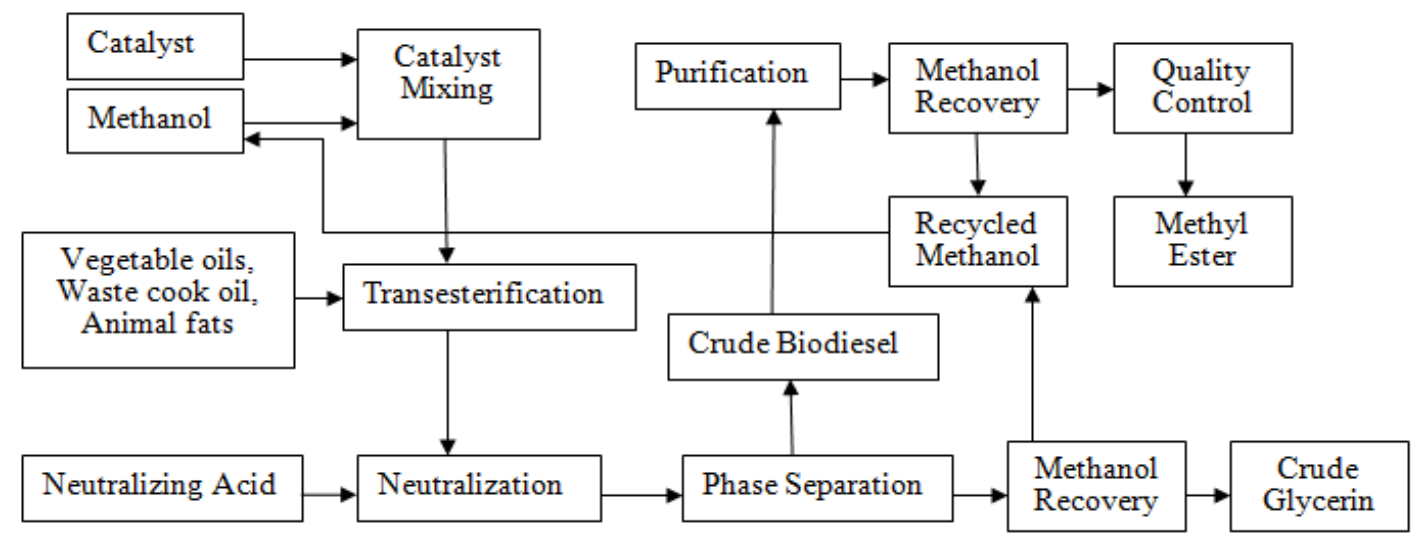

Fig. 1: Transesterification process of biodiesel production

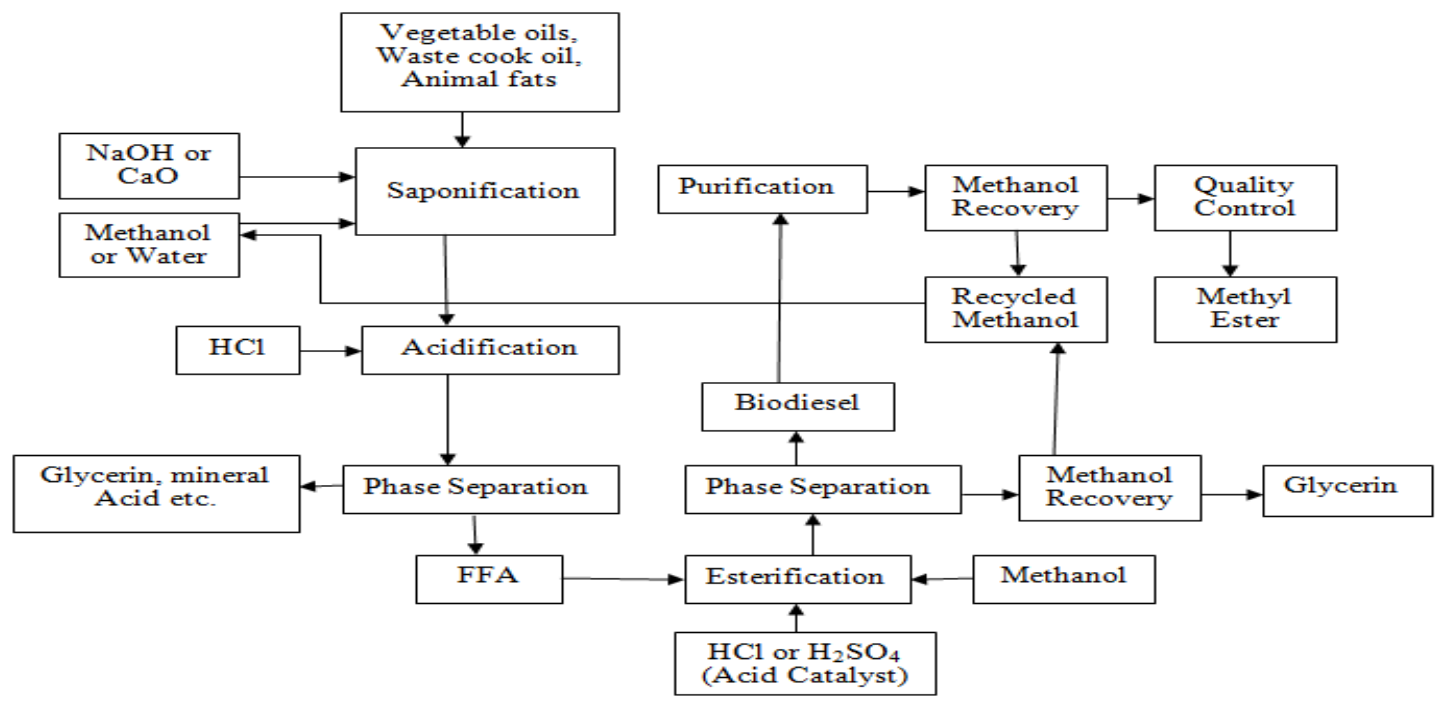

Fig. 2: Three-step method of biodiesel production

\section{POTENTIALITY OF BIODIESEL PRODUCTION IN BANGLADESH}

Bangladesh is an agricultural country, where grows any kind of seeds either it is edible or non-edible. If those plants from whose seeds biodiesel is produced cultivated here it is possible to get huge amount of seeds. The area of Bangladesh is about 147,570 square kilometers having a population of 138.8 million [18]. Being over populated country it is not possible to use edible oil sources for the biodiesel preparation purposes except the only choice is non-edible oil sources. The cultivable lands are can't be used for growing nonedible oil seeds because it is already using for growing edible oil seeds. So our only hope is the rail and road side areas as well as the lands which can't be used for cultivation purposes [18]. Amounts of unused land are not too much to grow a huge number of non-edible oil seeds, thus rail and road attracts our consciousness. Considering the oil content of those forest seeds described in the above section we have done our assumption on biodiesel production. Table 1 shows the potential places for non-edible oil seeds production and Table 2 shows the potentiality calculation for biodiesel production in Bangladesh.

Table 1. Potential places for non-edible oil seeds production

\begin{tabular}{|l|l|}
\hline Total road line & $=21040 \mathrm{Km}$ \\
\hline Total rail line & $=2835 \mathrm{Km}$ \\
\hline Total amount of road side & $=42080000 \mathrm{~m}$ \\
\hline Total amount of rail line side & $=5670000 \mathrm{~m}$ \\
\hline Distance between two trees & $=2 \mathrm{~m}$ \\
\hline Types of seeds & $=10$ \\
\hline Total number of each kind of seeds planted both sides of road and rail line & $=2387,500$ \\
\hline
\end{tabular}


Table 2. Potentiality calculation for biodiesel production in Bangladesh

\begin{tabular}{|c|c|c|c|c|c|c|}
\hline Species & $\begin{array}{l}\text { Oil content } \\
\text { of } \\
\text { kernel }(\%)\end{array}$ & $\begin{array}{l}\text { Yield } \\
(\%)\end{array}$ & $\begin{array}{c}\text { Seed from } \\
\text { each tree } \\
\text { (assumed) } \mathrm{Kg}\end{array}$ & $\begin{array}{c}\text { Total amount of } \\
\text { seed, } \mathrm{Kg}\end{array}$ & $\begin{array}{c}\text { Total amount } \\
\text { of oil (ton) }\end{array}$ & $\begin{array}{c}\text { Amount of } \\
\text { biodiesel (ton) }\end{array}$ \\
\hline Jaina & 68.05 & 79 & \multirow{10}{*}{5} & \multirow{10}{*}{2387,500} & 162470 & 128351 \\
\hline Nageswar & 65.26 & 82.45 & & & 155810 & 129322 \\
\hline Rubber & 46 & 50 & & & 109825 & 54913 \\
\hline Pitraj & 36.53 & 79 & & & 87215 & 68900 \\
\hline Bakul & 45.31 & 68 & & & 108180 & 73562 \\
\hline Palm & 60.22 & 79 & & & 143780 & 113586 \\
\hline Rata & 43.88 & 77 & & & 104764 & 80668 \\
\hline Karanja & 8.38 & 79 & & & 200073 & 158058 \\
\hline Chaulmoogra & 46.38 & 79.5 & & & 110735 & 88590 \\
\hline Ponyal & 58.38 & 76 & & & 139383 & 105931 \\
\hline Total & & & & & 1322,235 & 1001,881 \\
\hline
\end{tabular}

\section{COST ESTIMATION}

Here, studied cost estimation only for the process required for biodiesel preparation, cost of plantation not included because of lacking of their exact seed price. Kaniz et al. (2011) [19] describe the transesterification and three-step method for biodiesel preparation from waste cook oil. The production cost of biodiesel was calculated for transesterification and three-step method and the cost of biodiesel does not exceed $120 \mathrm{Tk}$. even the plantation will be included.

\subsection{Cost of biodiesel produced by transesterification method}

4.1.1 Base and acid catalyst transesterification method: Required amount of Chemicals for the production of $1.0 \mathrm{~L}$ of biodiesel yields $58 \%$ and $63.5 \%$ (wt/wt) for base and acid catalyst transesterification reported by Kaniz et al., (2011) [19] using $\mathrm{NaOH}$ as base catalyst and $\mathrm{H}_{2} \mathrm{SO}_{4}$ as acid catalyst. Required amount of oil (Waste cook oil) for base and acid catalyst were $1645 \mathrm{~mL}$ and $1475 \mathrm{~mL}$. Catalyst required $\mathrm{NaOH} 15 \mathrm{gm}$ and $\mathrm{H}_{2} \mathrm{SO}_{4} 30 \mathrm{~mL}$. Required amount of $\mathrm{CH}_{3} \mathrm{OH}$ for base and acid catalyst transesterification were $1175 \mathrm{~mL}$ and $1410 \mathrm{~mL} . \mathrm{CH}_{3} \mathrm{OH}$ recovered after base and acid catalyst transesterification method 530 $\mathrm{mL}$ and $635 \mathrm{~mL}$. Produced glycerin by base and acid catalyst transesterification method were $110.5 \mathrm{~mL}$ and $95.5 \mathrm{~mL}$ respectively. Table 3 shows the cost estimation for base and acid catalyst transesterification method. Biodiesel Cost is $102 \mathrm{Tk} / \mathrm{L}$ and $107 \mathrm{Tk} / \mathrm{L}$ for base and acid catalyst transesterification method respectively by using commercial grade chemicals.

\subsection{Cost of biodiesel produced by three-step method}

Required amount of Chemicals for the production of 1.0 L of biodiesel yield $79 \%$ (wt/wt) for three-step method reported by Kaniz et al., (2011) [19]. Required amount of oil are (Waste cook oil) $1300 \mathrm{~mL}, \mathrm{NaOH} 300 \mathrm{gm}$, $\mathrm{HCl} 450 \mathrm{~mL}, \mathrm{CH}_{3} \mathrm{OH} 900 \mathrm{~mL}$. Recovered amount of $\mathrm{CH}_{3} \mathrm{OH} 450 \mathrm{~mL}$ and produced glycerin $97.8 \mathrm{~mL}$ after three-step method.

Table 3.Cost estimation for base and acid catalyst transesterification method

\begin{tabular}{|c|c|c|c|c|}
\hline \multirow{4}{*}{} & \multicolumn{3}{|c|}{$\begin{array}{c}\text { Analytical } \\
\text { Grade }\end{array}$} & \multicolumn{2}{c|}{$\begin{array}{c}\text { Commercial } \\
\text { Grade }\end{array}$} \\
\cline { 2 - 5 } & $\begin{array}{c}\text { Base } \\
\text { (cat.) }\end{array}$ & $\begin{array}{c}\text { Acid } \\
\text { (cat.) }\end{array}$ & $\begin{array}{c}\text { Base } \\
\text { (cat.) }\end{array}$ & $\begin{array}{c}\text { Acid } \\
\text { (cat.) }\end{array}$ \\
\hline Component & Cost & Cost & Cost & Cost \\
\hline Raw oil Cost & 49.5 & 44.5 & 49.5 & 44.5 \\
\hline $\mathrm{H}_{2} \mathrm{SO}_{4}$ & 15 & 36 & 0.6 & 0.5 \\
\hline $\mathrm{CH}_{3} \mathrm{OH}$ & 846 & 1015 & 94 & 112.8 \\
\hline $\begin{array}{c}\mathrm{Recovery}_{\mathrm{CH}} \mathrm{OH} \\
\mathrm{CH}_{3} \mathrm{OH} \\
\text { TK./L }\end{array}$ & 382 & 458 & 42.5 & 50.8 \\
\hline
\end{tabular}

Table 4. Cost estimation for three-step method.

\begin{tabular}{|c|c|c|}
\hline \multicolumn{3}{|c|}{ Cost calculation } \\
\hline & $\begin{array}{c}\text { Analytical } \\
\text { Grade }\end{array}$ & $\begin{array}{c}\text { Commercial } \\
\text { Grade }\end{array}$ \\
\hline Component & Cost(TK.) & Cost(TK.) \\
\hline Raw oil & 39.5 & 39.5 \\
\hline $\mathrm{NaOH}$ & 300 & 12 \\
\hline $\mathrm{CH}_{3} \mathrm{OH}$ & 648 & 72 \\
\hline $\mathrm{HCl}$ & 396 & 2.25 \\
\hline $\begin{array}{c}\text { Recovered } \\
\mathrm{CH}\end{array}$ OH & 324 & 36 \\
\hline $\begin{array}{c}\text { Biodiesel cost } \\
\text { TK./L }\end{array}$ & 1059.5 & 89.75 \\
\hline
\end{tabular}

Cost of biodiesel: $89.75 \mathrm{Tk} / \mathrm{L}$ by using commercial grade chemicals without deducing the profit of produced glycerin. 


\section{CONCLUSION}

Bangladesh imported 916,000 tons of diesel and furnace oil per year. By using the potential sources for biodiesel production, we can reduce the dependency on imported oils. According to this oil contents and yields we prepared estimation on biodiesel production from different non-edible oil seeds which can be planted through the rail and road sides of Bangladesh. From this estimation it is seen that about 2387,500 ton seeds can be produced per year which supplies 1322,235 ton oil leading with 1001,881 ton biodiesel. That means a great opportunity for Bangladesh to survive a long time along with the developed world. The production cost of biodiesel is less than $120 \mathrm{Tk}$. by using commercial reagents for different methods. The present study supports that biodiesel can be a potential energy source for our country.

\section{RREFERENCES}

[1].http://www.iea.org/weo/docs/.../WEO2011_Press_L aunch_London.pdf [Accessed 19 July 2012].

[2].http://earthtrends.wri.org/pdf_library/country_profil es/ene_cou_050.pdf [Accessed 19 July 2012].

[3]. http://www.iea..gov/Bangladesh/proven/oil/ [Accessed 18 July 2012].

[4]. H. Noureddini, X. Gao. R.S. Philkana. Bioresource Technology 96 (2005); 769-777.

[5]. F. Ma, M.A. Hanna, Bioresour Technol., 70 (1999), 1.

[6]. G Knothe, J.V. Gerpen and J. Krahl, The Biodiesel Handbook. AOCS Press, Illinois, 2005.
[7]. http://www.bangladeshchronicle.net/2012/02/govtto-borrow-2b-for-fuel-oil-import/ [Accessed 18 July 2012].

[8]. www.economywatch.com/energy-economy/ scenario.html [Accessed 18 July 2012].

[9]. http://epbd.com/site/index.php?limitstart=3 [Accessed 19 July 2012].

[10]. M. N. Nabi, S. M. N. Hoque and M. S. Akhter, (2009), Fuel Processing Technology, 90 (2009) 1080.

[11]. L. Guerreiro, J.E. Castanheiro, I.M. Fonseca, R.M. Martin-Aranda, A.M. Ramos, J. Vital, Catalysis Today, 118 (2006) 166.

[12]. Dora E. López, James G.Goodwin Jr., David A. Bruce, Journal of Catalysis, 245 (2007) 381.

[13]. L.C. Meher, D. Vidya Sagar, S.N. Nnik, Renewable and sustainable Energy Review, 10 (2006) 248.

[14]. B.K. De and Bhattacharyya, Wiley-VCH Verlag GmbH, D-69451 Weinheim,1999 p. 404.

[15]. Siti Zullaikah, Chao-Chin Lai , Shaik Ramjan Vali, Yi-Hsu Ju, Bioresource Technology 96 (2005) 1889.

[16]. Mahbub Morshed, Kaniz Ferdous, Maksudur R. Khan, M.S.I Mazumder, M.A. Islam and Md. T. Uddin, Fuel 90 (2011) 2981.

[17]. Lotero Edgar, Liu Yijun,Dora E. Lopez, Kaewta Suwannakarn, David A. Bruce and James G. Goodwin Jr., Ind. Chem. Res. 44 (2005); 5353.

[18]. www.banglapedia.com [Accessed 5 April 2010].

[19]. Kaniz Ferdous, M. Rahim Uddin , Rehnuma Islam, M. Rakib Uddin, Maksudur R Khan., M. A. Islam, Proceedings of the International Conference on Mechanical Engineering and Renewable Energy (ICMERE-2011), 22- 24 December, Chittagong, Bangladesh (2011). 